\title{
Karakteristik Kawasan Wisata di Desa Ngunut Kabupaten Bojonegoro dengan Konsep Community Based Tourism
}

\author{
Cindy Nur Aziza Rahman dan Hertiari Idajati \\ Jurusan Perencanaan Wilayah Dan Kota, Fakultas Teknik Sipil Dan Perencanaan, \\ Institut Teknologi Sepuluh Nopember (ITS) \\ Jl. Arief Rahman Hakim, Surabaya 60111 Indonesia \\ email: ide_archits@yahoo.com
}

\begin{abstract}
Abstrak-Kecamatan Dander memiliki 2 kawasan wisata andalan yang berada di wilayah Perhutani yaitu Water Fun Ngunut yang terletak di Desa Ngunut dan Wana Tirta terletak di Desa Dander. Dalam penelitian ini fokus studinya berada di ODTW Water Fun Ngunut, karena pengelolaan obyek wisata ini lebih melibatkan masyarakat dengan pembagian hasil $70 \%$. untuk masyarakat dan $30 \%$ untuk perhutani. Namun pengelolaan ODTW ini belum maksimal. Sehingga tujuan penelitian ini adalah untuk mengindentifikasi variabel-variabel karakteristik kawasan wisata ngunut berdasarkan indikator Community Based Tourism dengan menggunakan teknik konten analisis. Hasil penelitian menunjukkan karakteristik kawasan wisata sesuai indikator Community Based Tourism antara lain terdapat partisipasi masyarakat dalam perencanaan, serta pokdarwis menjadi pengelola aktif dalam kegiatan wisata. Hasil penelitian ini merupakan salah satu tahapan dalam melakukan penelitan lanjutan yaitu merumuskan strategi pengembangan.
\end{abstract}

Kata Kunci-Community Based Tourism, Karakteristik Wisata, Wisata Bojonegoro, Wisata Ngunut.

\section{PENDAHULUAN}

$\mathrm{P}$ ARIWISATA adalah salah satu jenis industri baru yang mampu menghasilkan pertumbuhan ekonomi yang cepat dalam penyediaan lapangan kerja, peningkatan penghasilan, standart hidup serta menstimulasi sektor-sektor produktifitas lainnya [1]. Berdasarkan data statistik, tercatat bahwa sektor pariwisata memberikan kontribusi yang cukup besar terhadap perekonomian nasional. Pada periode januari-juli 2014 penerima devisa diperkirakan US\$ 5,5 milyar (Yahya, 2015). Secara ekonomi pariwisata memberi dampak dalam perluasan lapangan usaha dan kesempatan kerja, peningkatan income per kapita dan peningkatan devisa negara.

Namun, pariwisata tersebut tidak memberikan manfaat yang besar bagi masyarakat sekitar [3]. Manfaat terbesar dari kemajuan pariwisata di Indonesia sangat dirasakan oleh investor-investor yang memiliki modal besar untuk membangun segala fasilitas yang menunjang di area wisata. Oleh sebab itu, mulai bermunculan desa-desa wisata yang menerapkan konsep Community Based Tourism, dimana masyarakat secara bersama-sama membangun dan mengelola wisata [3].

Water Fun Ngunut merupakan salah satu wisata dimana masyarakat sebagai pengelola wisata, yaitu POKDARWIS atau kelompok sadar wisata [4]. Water Fun Ngunut berlokasi di wilayah hutan produksi perhutani Kecamatan Dander Kabupaten Bojonegoro. Selain water fun Ngunut, terdapat satu lagi objek wisata yang terletakt di wilayah perhutani yaitu Wana Tirta Dander. Wana Tirta Dander di kelola oleh perhutani dan dinas pariwisata [4].

Dibading dengan wanatirta dander yang dikelola oleh perhutani dan dinas parwisata, objek wisata water fun ngunut lebih menguntungkan untuk masyarakat karena objek wisata tidak dikelola oleh Dinas Kebudayaan dan Pariwisata maupun perhutani. Hanya terdapat pembagian hasil antara masyarakat memperoleh sebesar $70 \%$ dan $30 \%$ untuk perhutani dari pengelolaan wisata [5].

Namun usaha-usaha pengembangan pariwisata yang berorientasi pada masyarakat lokal masih minim. Hal ini dikarenakan pada dasarnya tidak memiliki latar belakang pengalaman atau pekerjaan di bidang wisata, sehingga belum memiliki kemampuan untuk terlibat dalam pengelolaan wisata [6]. Selain itu, kurangnya kepedulian masyarakat sekitar kawasan wisata untuk dapat berpartisipasi mengembangkan objek wisata dikarena pola pikir yang ingin mendapat hasil instan [7]. Serta kebiasaan masyarakat yang menggunakan sumber air sebagai aktifitas sehari-hari seperti mandi cuci dapat menghambat pengembangan wisata [5]. Dan juga wilayah objek wisata yang terletak di kawasan perhutani maka diperlukan adanya pemanfaatan sumberdaya yang konservatif [4].

Pengembangan wisata berbasis Community Based Tourism atau CBT, termasuk didalamnya memberi nilai yang besar bagi masyarakat, serta keuntungan/orientasi jangka panjang [8]. Wisata berbasis Community Based Tourism ini dilakukan dengan bentuk memberikan kesempatan dalam manajemen dan pembangunan pariwisata yang berujung pada pemberdayaan politis melalui kehidupan yang lebih demokratis termasuk dalam pembagian keuntungan dari kegiatan dari kegiatan pariwisata yang adil bagi masyarakat lokal [9].

Berdasarkan latar belakang permasalahan tersebut maka pada penelitian ini akan mengedintifikasi karakteristik kawasan wisata Water Fun Ngunut Kecamatan Dander Kabaten Bojonegoro. 


\section{METODE PENELITIAN}

\section{A. Variabel Penelitian}

Variabel merupakan atribut atau sifat atau nilai dari orang, objek atau kegiatan yang mempunyai variasi terntentu yang di tetapkan oleh peneliti sehingga dapat dipelajari dan di tarik kesimpulannya [11]. Adapun variabel dalam penelitian ini adalah sebagai berikut :

Tabel 1

Variabel Mengidentifikasi Karakteristik Kawasan Wisata di Desa Ngunut Kabupaten Bojonegoro

\begin{tabular}{ll}
\hline \multicolumn{1}{c}{ Variabel } & \multicolumn{1}{c}{ Sub variabel } \\
\hline Keterkibatan & Masyarakat terlibat dalam perencanaan \\
masyarakat & Masyarakat terlibat dalam pengelolaan \\
Manfaat yang & Peningkatan pendapat \\
diterima masyarakat & Lapangan pekerjaan baru \\
Peran komunitas & - \\
Keunikan lokal & Tradisi \\
& Budaya \\
Keunikan atraksi & - \\
\hline \hline Sumber : Hasil sintesa pustaka, 2016
\end{tabular}

\section{B. Responden Penelitian}

Pemilihan responden penelitian ini menggunakan teknik non probalistik sampling dengan menggunakan metode stakeholder analisis dengan beberapa kriteria responden. Adapun kriteria responden adalah sebagai berikut :

\section{Masyarakat}

a. Responden yang tinggal di daerah sekitar kawasan bisata Desa Ngunut Kecamatan Bojonegoro

b. Responden yang memahami kondisi lapangan

c. Responden termasuk di dalam kelompok masyrakat

d. Responden yang sesuai hasil stakeholder analysis

\section{Pemerintah}

a. Responden yang mengerti tentang Kawasan Wisata di Desa Ngunut Kecamatan Dander

b. Responden yang memahami kondisi lapangan

c. Responden yang berkompeten di bidangnya

d. Responden yang sesuai hasil stakeholder analysis

\section{Swasta}

a. Responden yang tinggal di sekitar kawasan wisata Desa Ngunut Kecamatan Dander

b. Responden memiliki usaha yang mendukung dalam pengembangan wisata

c. Responden yang sesuai hasil stakeholder analysis

Maka stakeholder terpilih adalah
a. Bappeda Kabupaten Bojonegoro (Kasubid Perindustrian Perdagangan Koperasi dan Investasi)
b. Dinas Pariwisata dan Kebudayaan Kabupaten Bojonegoro (Ka. UPT Agropolitan Desa Wisata)
c. Kecamatan Dander (Kasi. Pengembangan Masyarakat Kec. Dander)
d. Desa Ngunut (Kepala Desa Ngunut)
e. Pendamping KDKT Agropolitan Kecamatan Dander f. Perwakilan Komunitas yang terlibat

\section{Teknik Pengumpulan Data}

Teknik pengumpulan data yang digunakan dalam penelitian ini adalah teknik Wawancara mendalam (in-depth interview) adalah proses memperoleh keterangan untuk tujuan penelitian dengan cara tanya jawa sambil bertatap muka antara pewawancara dengan informan atau orang yang diwawancarai.

\section{Teknik Analisis}

Pada analisis mengidentifikasi karakteristik sesuai indikator CBT digunakan teknik Analysis Content. Analisis Isi bukan sekedar menjadikan isi pesan sebagai obyeknya, melainkan lebih dari itu terkait dengan konsep sikonsepsi yang lebih baru tentang gejala-gejala simbolik dalam duniakomunikasi [10].

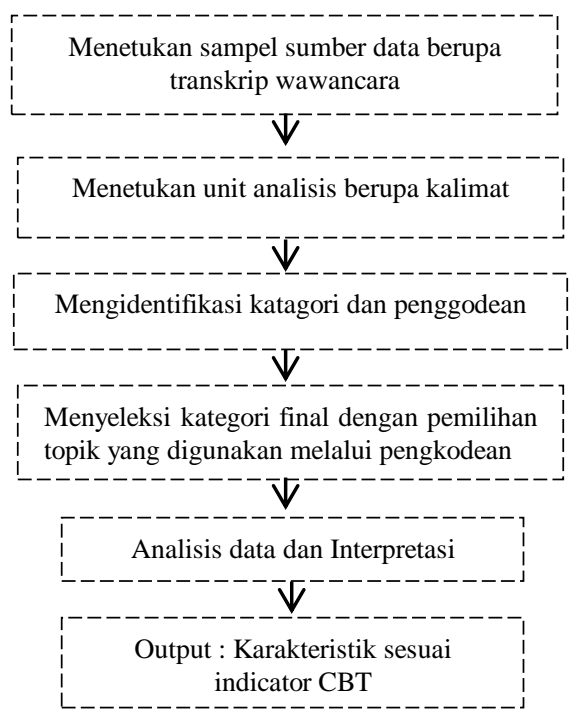

Gambar 1. Proses Analisis Konten dalam Mengidentifikasi Karakteristik Kawasan Wisata Ngunut Kabupaten Bojonegro

Sumber : Peneliti, 2016

\section{HASIL DAN PEMBAHASAN}

Penelitian ini bertujuan untuk mengidentifikasi Karakteristik Kawasan Wisata Berbasis Community Based Tourism di Desa Ngunut Kecamatan Dander Bojonegoro, dengan menggunakan Content Analysis. Dari varaiabel yang telah ditetpkan peneliti melakukan wawancara kepada kelompok stakeholder pemerintah, swasta dan masyarakat. Dalam menganalisis karakteristik kawasan wisata sesuai indikator CBT di Kecamatan Dander Kabupaten Bojonegoro dilakukan pengkodean yang telah tetapkan sebelumnya. Berikut ini keterangan dari kode-kede yang digunakan dalam analysis content dalam penelitian ini :

- P1 (Pemerintah $1:$ Kepala Desa Ngunut) :Nur Hidayati

- P2 (Pemerintah 2 : Ka. UPT Angropolitan dan Desa Wisata) : Dyah Enggarini Mukti, SE, MM

- P3 (Pemerintah 3 : Kasi Pengembangan Masyarakat Kecamatan Dander) : Dian Rakhmawati

- P4 (Pemerintah 4 : Kasubid Perindustrian Perdagangan Koperasi dan Investasi Bappeda Bojonegoro) : Ike Widiyaningrum, S.sos

- M1 (Masyarakat 1 : Pendamping KDKT Agro) : Dodik Eko Cahyono

- M2 (Masyarakat 2 : Ketua PKK) : Listari 
- M3 (Masyarakat 3 :Ketua Pokdarwis) : Pak Nya'in

- M4 (Masyarakat 4 : Ketua BUMdes dan pemilik warung): Lasmijan

- M5 (Masyarakat 5 :Ketua LMDH): Mudofar, Spd

Untuk angka setelah tanda titik pertama menujukkan kalimat pada dialog ke-n

Untuk angka setelah tanda titik kedua menujukkan kalimat pada dialog ke $n$ baris ke-n

Contoh : P2.16.6

Artinya : Pemerintah 2. Kalimat pada dialog ke 16. Line 6 P2.16

Dalam menganalisis karakteristik wisata sesuai dengan indikator CBT dilakukan pengkodean sesuai kode-kode yang telah ditetapkan sebelumnya. Berikut ini karakteristik berdasarkan hasil dari content Analysis :

Tabel 2

Hasil Analisis Konten Analisis Terkait Karakteristik Kawasan Wisata di Kecamatan Dander Kabupaten Bojonegoro

\begin{tabular}{|c|c|c|c|}
\hline Variabel & Subvariabel & Kode & Karakteristik \\
\hline \multirow[t]{2}{*}{$\begin{array}{l}\text { Masyarkat } \\
\text { terlibat } \\
\text { langsung } \\
\text { masyarakat }\end{array}$} & $\begin{array}{l}\text { Masyarakat } \\
\text { terlibat dalam } \\
\text { perencanaan }\end{array}$ & $\begin{array}{l}\text { P1.1, } \\
\text { P2.5, } \\
\text { M1,4, } \\
\text { P2.6.7, } \\
\text { M1.7. } \\
\text { 10M1 } \\
7.9 . \mathrm{M} \\
1.1\end{array}$ & $\begin{array}{l}\text { Masyarakat terlibat dalam } \\
\text { merencanakan namun masih } \\
\text { belum ada inisiatif masyarakat } \\
\text { dalam pengembangan }\end{array}$ \\
\hline & $\begin{array}{l}\text { Masyarakat } \\
\text { terlibat dalam } \\
\text { pengelolaan }\end{array}$ & $\begin{array}{l}\text { P2.4, } \\
\text { P2.1.4, } \\
\text { P3.10 }\end{array}$ & $\begin{array}{l}\text { Masyarakat yang terlibat dalam } \\
\text { pengelolaan adalah masyarakat } \\
\text { yang bergabung dalam } \\
\text { pokdarwis }\end{array}$ \\
\hline \multirow[t]{2}{*}{$\begin{array}{l}\text { Keuntungan } \\
\text { yang di } \\
\text { terima } \\
\text { masyarakat }\end{array}$} & $\begin{array}{l}\text { Peningkatan } \\
\text { pendapatan }\end{array}$ & $\begin{array}{l}\text { P1.1.2 } \\
1, \\
\text { P2.13, } \\
\text { P2.37. } \\
\text { P3.33, } \\
\text { M1.31 } \\
\text { P1.17. } \\
6\end{array}$ & $\begin{array}{l}\text { Pendapatan masyarakat yang } \\
\text { membuka warung di sekitar } \\
\text { wisata meningkat }\end{array}$ \\
\hline & $\begin{array}{l}\text { Membuka } \\
\text { lapangan } \\
\text { perkerjaan } \\
\text { baru }\end{array}$ & $\begin{array}{l}\text { P3.32, } \\
\text { M1.31 }\end{array}$ & $\begin{array}{l}\text { Dengan adanya wisata } \\
\text { masyarakat dapat terlibat } \\
\text { dengan membuka usaha } \\
\text { sekaligus membantu } \\
\text { pengelolaan wisata }\end{array}$ \\
\hline \multirow[t]{5}{*}{$\begin{array}{l}\text { Peran } \\
\text { Komunitas }\end{array}$} & - & $\begin{array}{l}\text { P2.1, } \\
\text { P2.31 }\end{array}$ & $\begin{array}{l}\text { Pokdarwis secara penuh } \\
\text { berperan dalam mengelola } \\
\text { wisata }\end{array}$ \\
\hline & & $\begin{array}{l}\text { M1.5, } \\
\text { P1.17 }\end{array}$ & $\begin{array}{l}\text { Untuk kelompok lain selain } \\
\text { Pokdarwis berpearan tidak } \\
\text { penuh dalam pengelolaan, } \\
\text { namun untuk saat ini hanya } \\
\text { terlibat dalam } \\
\text { musywarah/merencanakan }\end{array}$ \\
\hline & & $\begin{array}{l}\text { P1.1, } \\
\text { M4.10 } \\
\text { P3.3, } \\
\text { M4.1 }\end{array}$ & $\begin{array}{l}\text { LMDH ikut serta sebagai } \\
\text { pengelola di Pokdarwis namun } \\
\text { hanya beberapa }\end{array}$ \\
\hline & & $\begin{array}{l}\text { P1.18, } \\
\text { M5.5 }\end{array}$ & $\begin{array}{l}\text { Bumdes menangui terkait } \\
\text { keuangan dalam usaha desa } \\
\text { yang dilakukan oleh masyarakat }\end{array}$ \\
\hline & & $\begin{array}{l}\text { P1.18, } \\
\text { P2.4 }\end{array}$ & $\begin{array}{l}\text { Dalam pengelolaan wisata } \\
\text { karang taruna berperan pada hal } \\
\text { teknis seperti mengelola parkir, } \\
\text { mengawi atraksi nginter }\end{array}$ \\
\hline
\end{tabular}

M2.5, PKK tidak terlibat dalam

M2.20 pengelolaan wisata, namun

, terlibat dalam penyedian produk

M2.22 penunjang wisata, namun

, perannya belum optimal

M2.30

Keunikan Tradisi $\quad$ P1.34, Terdapat tradisi sdekah bumi

lokal P3.29, yang diadakan setahun sekali

M1.28

M3.35

M5.38

P2.39. Nasi Grintil merupakan

3, keunikan budaya masyarakat

P3.23, dander yang mana nasi tersebut

P3.25, terbuat dari singkong

\begin{tabular}{lll} 
Keunikan & M1.27 & \\
Atraksi & P4.2, & Menyajikan seumber air yang \\
& M1.26 & bersih dengan suasana sejuk di \\
& area hutan dan terdapat atraksi \\
& M3.63 & nginter \\
\hline
\end{tabular}

Sumber:hasil analisis, 2016

Adapaun karakteristik wisata sesuai indikator CBT adalah sebagai berikut masyarakat terlibat dalam merencanakan namun masih belum ada inisiatif masyarakat dalam pengembangan. Masyarakat yang terlibat dalam pengelolaan adalah masyarakat yang bergabung dalam pokdarwis. Pendapatan masyarakat yang membuka warung di sekitar wisata meningkat. Dengan adanya wisata masyarakat dapat terlibat dengan membuka usaha sekaligus membantu pengelolaan wisata. Pokdarwis secara penuh berperan dalam mengelola wisata. Untuk kelompok lain selain Pokdarwis berpearan tidak penuh dalam pengelolaan, namun untuk saat ini hanya terlibat dalam musywarah/merencanakan. LMDH ikut serta sebagai pengelola di Pokdarwis namun hanya beberapa. Bumdes menangui terkait keuangan dalam usaha desa yang dilakukan oleh masyarakat. Dalam pengelolaan wisata karang taruna berperan pada hal teknis seperti mengelola parkir, mengawi atraksi nginter. PKK tidak terlibat dalam pengelolaan wisata, namun terlibat dalam penyedian produk penunjang wisata, namun perannya belum optimal.

Terdapat tradisi sdekah bumi yang diadakan setahun sekali. Dan juga terdapat Nasi Grintil merupakan keunikan budaya masyarakat dander yang mana nasi tersebut terbuat dari singkong. Selain itu terdapat keunikan atraksi berupa Nginter dengan seumber air yang bersih dengan suasana sejuk diarea hutan dan terdapat atraksi nginter.

\section{KESIMPULAN/RINGKASAN}

Berdasarkan hasil analisis yang telah dilakukan mengenai Karakteristik kawasan wisata sesuai indikator CBT di Kecamatan Dander Kabupaten Bojonegoro yang telah diuraikan sebelumnya, maka dapat ditarik kesimpulan antara lain terdapat partisipasi masyarakat dalam perencanaan, serta pokdarwis menjadi pengelola aktif dalam kegiatan wisata. Dengan adanya wisata memberikan maanfaat untuk masyarakat baik itu dengan meningkatnya pendapatan masyarakat ataupun adanya lapangan pekerjaan baru untuk masyarakat. Adanya 
keunikan lokal berupa tradisi sedekah bumi dan budaya nasi goreng jrintil. Selain itu, terdapat keunikan atraksi yaitu atraksi ngintri di area hutan dengan suasana yang sejuk.

\section{DAFTAR PUSTAKA}

[1] Pandit, Nyoman, S. 1999. Ilmu Pariwisata, Sebuah Pengantar Perdana. Jakarta: PT Pradnya Paramita.

[2] Yahya, Arief. 2015. Pembangunan Infrastruktur untuk Peningkatan Daya Saing Pariwisata. http://musrenbangnas.bappenas.go.id/files/pr amus/penutupan/1.\%20paparan\%20menteri\%20pariwisata.pdf.

[3] A'innun Filszah, dkk. 2015. Pengembangan Desa Wisata Melalui Konsep Community Based. Prostiding

[4] Data Kecamatan Dander 2015

[5] Dian Rachmawati.2015. Wawancara Wisata Dander di Kantor Kecamatan Dander

[6] Rachmawati, Eva. 2014. Mampukah Masyarakat Lokal Mengelola pariwisata?. Risalah Kebijakan Ligkungan Dan Pertanian. Vol. 1 No 1 hal 30-34

[7] Dodik Eko.2015. Wawancara Wisata Dander di Balai Desa Ngunut

[8] Dina, Yuniati. 2010. Pemetaan Dampak Ekonomi Pariwisata Dalam Penerapan Konsep Community-Based Tourism. UNS

[9] Purnamasari, Andi Maya. (2011), Pengembangan Masyarakat Untuk Pariwisata Di Kampung Wisata Toddabojo Provinsi Sulawisi Selatan, Jurnal Perencanaan Wilayah Dan Kota, Vol 22, 49-64

[10] Imam Subrayogo. 2001. Metodologi Penelitian Sosial-Agama. Bandung: Remaja Rosda Karya

[11] Darmawan, Deni. 2013. Metode Penelitian Kualitatif. Bandung : PT Remaja Rosdakarya 